\title{
Bioremediation of Pesticide-contaminated Soil: A Review on Indispensable Role of Soil Bacteria
}

\section{J.L.P.C. Randika ${ }^{1}$, P.K.G.S.S. Bandara ${ }^{2}$, H.S.M. Soysa ${ }^{3^{*}}$, H.A.D. Ruwandeepika ${ }^{4}$ and S.K. Gunatilake ${ }^{5}$}

Received: 08 ${ }^{\text {th }}$ January 2021 / Accepted: 30 $0^{\text {th }}$ September 2021

\begin{abstract}
Purpose: Scientists have identified a plenty of bacterial strains having ability to degrade pesticide residues accumulated in the environment. Due to wide variation of chemical properties of pesticides, a single strain may not be versatile. Hence, identification of bioremediation ability of various bacteria is important. This review focused on understanding and explaining the role of soil bacteria having pesticide detoxification ability.
\end{abstract}

Methodology: Previous research articles, book chapters and literature on bioremediation ability of different soil bacteria were reviewed and various strains of soil bacteria having bioremediation ability, mechanisms behind microbial bioremediation, factors affecting bioremediation and limitations and recent advancements of bioremediation were identified. Based on identified research gaps, further perspectives were introduced.

Findings: The results revealed that plenty of soil bacteria having a bioremediation potential have been identified worldwide. As the major mechanism of bioremediation, the microorganisms consume pesticidecontaminated in the soil as their energy or nutrient sources. Various factors such as Bioavailability, Substrate and Environmental factors effect on bioremediation potential. Biostimulation, Bioaugmentation, Biopiling, Composting, Bioreactors and Land farming are identified as popular bioremediation methods suiTable Ofor the bioremediation of pesticide contaminants. However, this technique still remains partially developed due to the lack of versatile microorganisms for detoxifying variety of different pesticides.

Originality/Value: As this is still a developing area, conducting further researches is timely important. Hence, reviewing literature and identifying already covered areas are important in mitigating the research gap. Therefore, focusing further research goals for the researchers is greatly helpful.

Keywords: Bioremediation, Environmental pollution, Pesticide detoxification, Pesticides, Soil microorganisms

\section{INTRODUCTION}

Production and use of synthetic pesticides have been dramatically increased after the end of the Second World War (Johnson and Talbot, 1983). Introduction of synthetic pesticides has massively contributed to the agriculture sector in controlling pests worldwide, thereby increasing the crop yield from agriculture. But, after applying these pesticidal chemicals into agricultural lands, the fate of these chemicals in the environment has formerly become a mystery. Later, scientists have identified that the
${ }^{1}$ Faculty of Graduate Studies, Sabaragamuwa University of Sri Lanka, P.O. Box 02, Belihuloya - 70140, Sri Lanka.

${ }^{2}$ Department of Bio systems Technology, Faculty of Technology, Sabaragamuwa University of Sri Lanka, P.O. Box 02, Belihuloya - 70140, Sri Lanka.

3* Department of Physical Sciences and Technology, Faculty of Applied Sciences, Sabaragamuwa University of Sri Lanka, P.O. Box 02, Belihuloya-70140, Sri Lanka.

sasimali@appsc.sab.ac.lk

${ }^{4}$ Department of Livestock Production, Faculty of Agricultural Sciences, Sabaragamuwa University of Sri Lanka, P.O. Box 02, Belihuloya-70140, Sri Lanka.

${ }^{5}$ Department of Natural Resources, Faculty of Applied Sciences, Sabaragamuwa University of Sri Lanka, P.O. Box 02, Belihuloya - 70140, Sri Lanka.

(D)https://orcid.org/0000-0003-3244-8670 
pesticides applied to the land can be either built up in the environment or degraded. Although the prolong existence of these chemicals may be an advantage for the sustained pest control, cumulative effect of residual accumulation can be adverse on the balance of environment and all living organisms including human beings. On the other hand, nature of the end products of natural degradation is distrustful because toxicity of the pesticide may be increased or decreased upon conversion to another compound (Menzie, 1972; Gavrilescu, 2005). As well, the persistence of pesticide residuals is also unrevealed because pesticide residuals are found in different matrices in the environment in different forms (Darko et al., 2008; Nag and Raikwar, 2011; Silva et al., 2019; Heshmati et al., 2020). The intensive and indiscriminate usage of pesticides has resulted in serious health issues both in human and other life forms, as well as there exist adverse side effects to the environment (Jeyaratnam, 1985; Kumar et al., 2013b; Sharma and Singhvi, 2017). Moreover, pesticide residue accumulation can happen in the tissues of living beings inhabited in pesticide contaminated environments and, transferred through food chains (Varo et al., 2002; Akan et al., 2013). On the other hand, Pesticide leaching into the soil and groundwater bodies is also an important cause to consider (Chen and Mulchandani, 1998). Although pesticides cause many adverse effects to the nature, necessity of pesticide usage is dramatically increased with the increase of world population. Increasing world population greatly increases the demand for food production leading to intensive agriculture, as there is limited land available for cultivation. This may also dramatically increase the future pesticide usage making the scenario worst (Stephenson et al., 2001; Popp et al., 2013). The adverse effects of pesticides are becoming increasingly clear on the natural ecosystem as well as on human health. In terms of overcoming these adverse impacts, discovery of rapid pesticide detoxification techniques is timely important. Bioremediation plays a great role in detoxifying residual pesticides in the environment.

The capability of various microorganisms to degrade or detoxify pesticides has been exploited. In the process of bioremediation, harmful compounds of pesticides are broken down into harmless non-toxic compounds through microbial metabolism. (Gavrilescu, 2005; Odukkathil and Vasudevan, 2013). Fungi, bacteria, cyanobacteria, actinobacteria and some of other microorganisms have been recognized with the capabilities of degrading pesticides. However, majority of identified soil microorganisms having such abilities are bacteria and fungi (Geetha and Fulekar, 2008; Odukkathil and Vasudevan, 2013; Uqab et al., 2016).

\section{Different Classifications of Pesticides}

For the purpose of identification, pesticides have been classified into groups using various classification methods. However, there are mainly three popular methods used for pesticide classification such as, classification based on the "mode of entry, target pests, and chemical type" (Yadav and Devi, 2017). In addition to the above three methods, classifications based on toxicity level, and mode of action can also be found (Akashe et al., 2018). In the classification based on 'mode of entry', the way how a particular pesticide come into contact with or enter into the target pest is considered. According to this classification, there are several classes of pesticides such as, "systemic, contact, fumigants, stomach poisons, and repellents" (Yadav and Devi, 2017; Akashe et al., 2018). Based on the target pests, pesticides are grouped into several categories such as, "insecticides, fungicides, rodenticides, algaecides, nematicides, acaricides, larvicides, aphicides, molluscicides, miticides, ixodicides, bactericides and herbicides" (Gilden et al., 2010; Yadav and Devi, 2017; Akashe et al., 2018). Based on the type of chemical, pesticides can be again grouped into several classes such as, "organic, inorganic, synthetic, and biological" (Council_on_Scientific_Affairs, 1997). Moreover, the chemical composition based classification of pesticides have grouped various pesticides into four main groups such as, "organophosphorus, organochlorine, carbamates, and pyrethroids" (Yadav and Devi, 2017). In addition to that, "arsenic compounds, mercury compounds, copper compounds, bipyridylium compounds, coumarin derivatives, nitrophenol derivatives, phenoxyacetic acid derivatives, triazine derivatives, organotin, 
pyrazoles, and thiocarbamates" are also some groups of pesticides classified, based on chemical composition (WHO, 2010). Based on toxicity level or $\left.\mathrm{LD}_{50}\right\urcorner$ value, pesticides have further been classified into several groups such as, "extremely hazardous, highly hazardous, moderately hazardous, slightly hazardous, and unlikely to present acute hazard" (WHO, 2010; Akashe et al., 2018). According to the mode of action, pesticides are classified into several groups such as, "physical poison, protoplasmic poison, respiratory poison, nerve poison, and chitin inhibition" (Akashe et al., 2018). Of major classes of common pesticides used in the world, majority accounts for herbicides $(47.5 \%)$ followed by insecticides (29.5\%), fungicides $(17.5 \%)$, and other pesticides $(5.5 \%)$ such as, bactericides, acaricides, rodenticides etc. (De et al., 2014; Sharma et al., 2019). Figure 01 shows the summary of the different classifications of pesticides in the world.

\section{Worldwide Usage of Pesticides}

Although a part of the people is focusing on negative attributes of pesticides, their worldwide usage in agriculture has become indispensable nowadays and a number of benefits from different types of pesticide have been identified (Cooper and Dobson, 2007; Popp et al., 2013; Mahmood et al., 2016). Some scientists argue that, if pesticides were to be abolished, the lives lost due to food shortage would be increased implying that the massive contribution of pesticides towards the augment of agriculture (Lomborg, 2001). De et al. (2014) have stated that the global pesticide consumption was around two million tons per year. However, by the year 2020, the global pesticide usage has been estimated to increase up to 3.5 million tonnes (Zhang, 2018; Sharma et al., 2019). From the total amount, $45 \%$ is used by Europe whereas, $25 \%$ and $3.75 \%$ are used by USA and India respectively, leaving the rest of the total amount to be used in other countries. However, the statistics of "Food and Agriculture Organization of United Nations" (FAO) indicate that out of the total world pesticide usage, 52.8 $\%$ is considered to be used by Asia whereas, 30.0 $\%$ is used by USA, $13.7 \%$ is used by Europe, 2.2 $\%$ is used by Africa and $1.3 \%$ used by Oceania. These data show that the highest average pesticide user is the Asian continent (FAO, 2020). However, there is a discrepancy between the statistics of these two sources. According to the FAO statistics, the world average pesticide usage has been increased drastically from 2285881.41 to 4113591.25 metric tons within a period of 27 years, since 1990 to 2017. Figure 02 summarizes the increasing pattern of average world pesticide usage from 1990 to 2017.

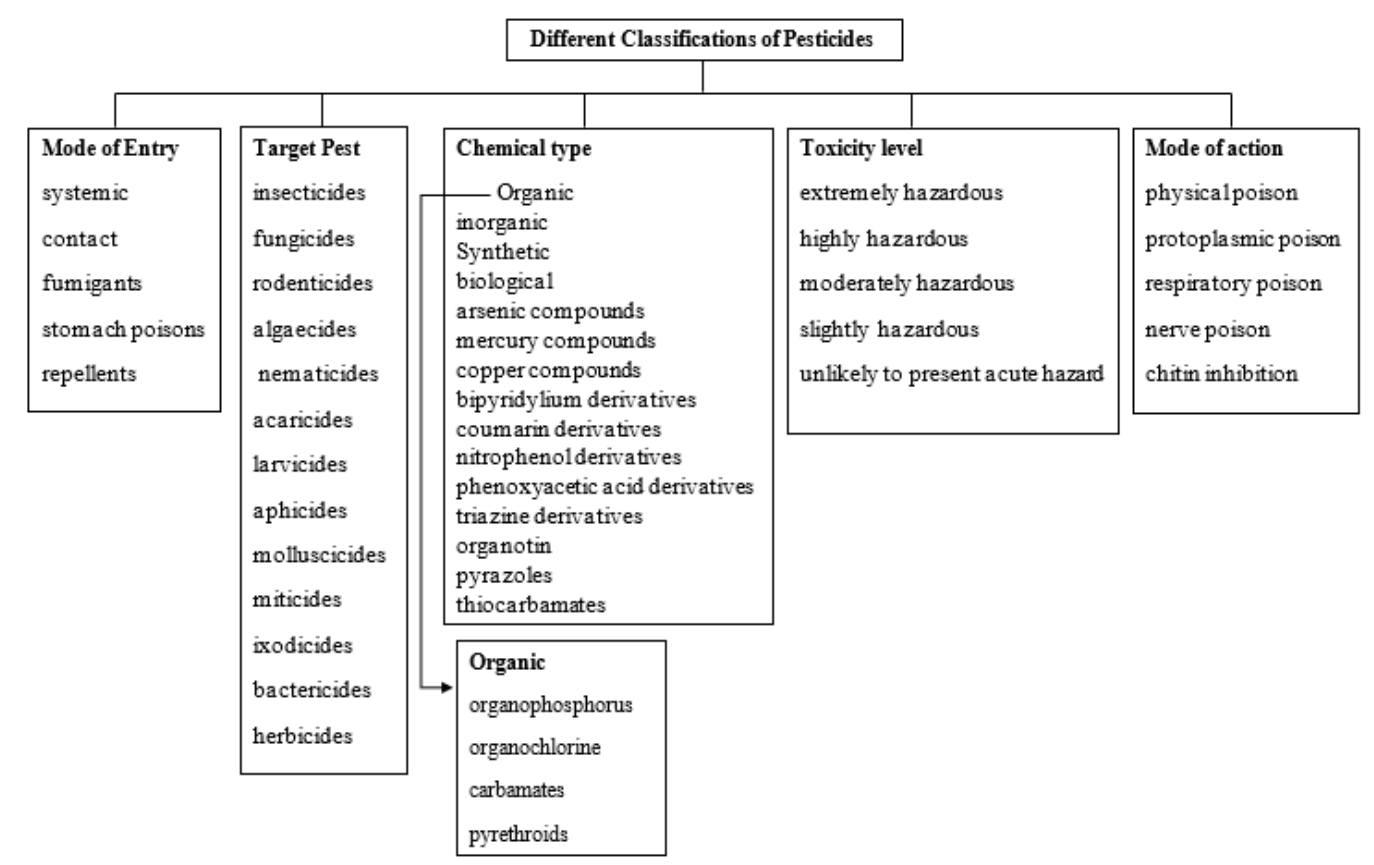

Figure 01: Different Classifications of Pesticides in the world 


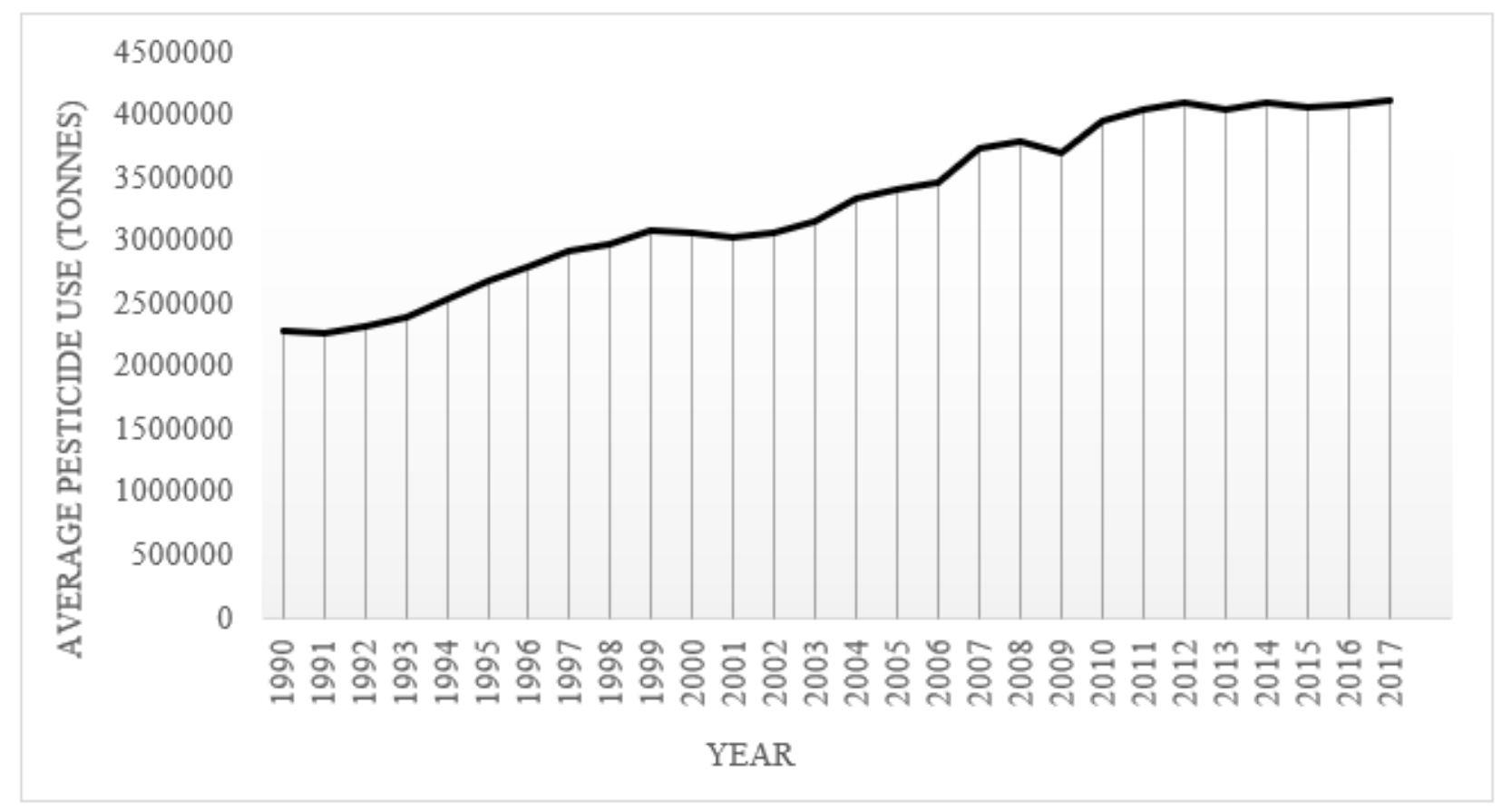

Figure 02: Increasing pattern of average world pesticide usage from 1990 to 2017

\section{Pesticides as Environmental Pollutants}

Although pesticides play a great role inagriculture, there is no doubt that they have some adverse impacts on the environment. Use of pesticide in high input agriculture is ineviTable 0and the extensive usage has created a greater threat to the ecosystem as well as to the human health (Carvalho, 2017). Due to the high toxicity and high biological activity of pesticides, they hold an exclusive position out of the other environmental contaminants. The effect of pesticides is not only on the target pest but also on the other non-target organisms such as, earthworms, natural predators and pollinators. Not only the terrestrial animals but also most of the aquatic animals, planktons, birds and microorganisms are also affected by the toxic effect of pesticides (Ware, 1980; Flexner et al., 1986; Smith and Stratton, 1986; Pereira et al., 2009). This can directly affect the balance of the natural ecosystem. Most of the previous studies have shown that only a very small percentage $(0.3 \%)$ of the entire amount of pesticides applied to a land reaches the target pest whilst the rest goes somewhere else (Pimentel, 1995; van der Werf, 1996) and although the pesticide is applied into a small area, it can spread over a vast area. After getting released into the environment, pesticides may have many different fates such as, retaining in the air, absorbing into the soil or dissolving in the water etc. Pesticide residues in the soil can reach surface water bodies through surface runoff or may contaminate the ground water by percolation (van der Werf, 1996; Yadav and Devi, 2017). The toxic compounds in pesticides mixed with surface water bodies can directly affect aquatic organisms. Moreover, pesticide residues could be accumulated in the tissues of living beings and transferred from one level to the next through food chains (Chen and Mulchandani, 1998). Human beings can also be directly or indirectly affected by the toxicity of pesticides (Chen and Mulchandani, 1998; Curl et al., 2002; Young et al., 2005; Binukumar and Gill, 2011; Yadav and Devi, 2017).

\section{Biodegradation vs Bioremediation}

Microorganisms or plants mediated transformation of toxic pollutants into less or more-toxic forms or total mineralization yielding water and either carbon dioxide or methane can be identified as biodegradation (Hutchinson et al., 2001; Singh and Ward, 2004). Bioremediation is a technological 
approach where the biodegradation ability of microorganisms or plants are methodically utilized in order to convert toxic pollutants into less or nontoxic compounds (Hutchinson et al., 2001; Singh and Ward, 2004; Das and Dash, 2014). Plant mediated bioremediation process is termed as phytoremediation (Singh and Ward, 2004). Since past, bioremediation has been used in waste water treatments. Now a days, this technology has been further developed and used globally (Iqbal and Bartakke, 2014). Moreover, bioremediation is considered as a safe, cheaper and environmentally sound method of sequestering harmful contaminants from the natural ecosystem (Das and Dash, 2014; Bhardwaj et al., 2019). Microbial bioremediation can effectively be used in detoxifying toxic pesticide residues built up in the environment and an ample number of studies have been conducted in this regard worldwide. In natural habitats, microorganisms are generally existing as consortia which are more efficient than single strains in degrading pesticides and as a result, a microbial consortium can degrade different types of pesticides simultaneously (GóngoraEcheverría et al., 2020). In some studies, they have tested the bioremediation ability of some natural soil microorganism consortia whereas, some scientists have isolated microorganisms followed by testing the individual ability of microbes to degrade pesticides (McAllister et al., 1996; Geetha and Fulekar, 2008; Massiha et al., 2011; Werren, 2012). In addition to the soil and water inhabited bacteria, some studies have revealed that some microbes in the gut microbiota of some insects have the capability of degrading some insecticides (Almeida et al., 2017).

\section{Mechanism of Microbial Bioremediation}

As far as the mechanism of microbial degradation of contaminants like pesticides is concerned, most of the microorganisms consume the contaminants as their energy or nutrient sources. They degrade some pollutants in order to gain nutrients or energy released during the breaking down of chemical bonds. As a result of this microbial degradation, the initial harmful substances are converted into less or nontoxic byproducts. Basically, this is the principle behind the microbial bioremediation
(Bollag and Liu, 1990; Aislabie and LloydJones, 1995; Boopathy, 2000; Karigar and Rao, 2011; Das and Dash, 2014). Most of the studies have revealed that various microorganisms having ability to degrade toxic compounds utilize those compounds as their sole carbon source (Sethunathan and Yoshida, 1973; Saber and Crawford, 1985; Chaudhry et al., 1988; Struthers et al., 1998; Cycoń et al., 2009). Whereas, some microorganisms use pollutants as a substrate to fulfill their nitrogen requirement (Struthers et al., 1998; Wang et al., 2005; Iwaki et al., 2007). Various mechanisms such as, aerobic, anaerobic and chemolithotrophic metabolism, metabolism via extracellular enzymes, and fermentation are used by different microorganisms to degrade organic pollutants (Bollag and Liu, 1990).

In most of the reported cases, enzymatic degradation has been identified as one of the major mechanisms used by microorganisms in bioremediation process (Scott et al., 2008; Scott et al., 2011; Odukkathil and Vasudevan, 2013; Uqab et al., 2016). Some microorganisms are capable of producing enzymes that can degrade the active ingredients of pesticides. These enzymes act as potential factors for bioremediation of pesticide contaminants. However, due to the broad diversity of the pesticide chemistry, a wide range of enzyme groups may be required for bioremediation of pesticides (Scott et al., 2008). Oxidoreductases, monooxygenases, dioxygenases, hydrolases, phosphotriesterases, lyases, haloalkane dehydrochlorinases, laccases, peroxidases, lipases, cellulases, and proteases can be considered as some of the major enzyme groups that play a significant role in pesticide bioremediation (Scott et al., 2008; Karigar and Rao, 2011). With the intervention of these enzymes, substrates may be subjected to the reactions such as, "oxidation, hydroxylation, denitrification, desulfurization, dehalogenation, demethylation, ammonification, decarboxylation, and hydrolysis" based on the chemical structure of the pesticides (Karigar and Rao, 2011). Co-metabolism is another way by which microorganisms transform toxic pollutants into other forms of compounds indirectly without utilizing them as a nutrient or energy source (Bollag and Liu, 1990). 
Demobilization of contaminants is also another mechanism in bioremediation. Microorganisms can demobilize contaminants through different ways such as, sorption or accumulation of organic pollutants by microbial biomass, precipitation of toxic elements by producing reduced or oxidized forms, and polymerization or conjugation of organic molecules of pollutants by linking with each other or with natural compounds in the environment. Secondary effects of microbial activities may be helpful for the bioremediation process. In this scenario, toxic compounds are transformed into less or nontoxic substances due to the environmental changes such as, $\mathrm{pH}$, redox conditions, and reactive products generated due to microbial activities in the polluted environment (Bollag and Liu, 1990).

Scientists have identified some genes in bacterial genomes involved in bioremediation of pesticides (Aislabie and LloydJones, 1995; Chen and Mulchandani, 1998; Das and Dash, 2014). Numerous genes significant for the formation of catabolic enzymes associated with microbial degradation of pollutants have been identified to be present in plasmids of bacteria. Evolution of the bacteria in order to gain new derivative capabilities and adaptations to environments contaminated with xenobiotic compounds are dramatically supported by these plasmid genes (Bollag and Liu, 1990). With technological advancements, scientists are working on developing microbial strains with novel catabolic capabilities that can be used in bioremediation by genetic engineering technologies (Jafari et al., 2013; Kumar et al., 2013a; Das and Dash, 2014; Gupta and Singh, 2017; Kumar et al., 2018).

\section{Factors Affecting Bioremediation Limitations of Bioremediation}

Optimization and control of bioremediation is a complex procedure driven by many factors (Das and Dash, 2014). There are various factors affecting bioremediation potential and they can be discussed as below.

\section{Bioavailability}

Presence of microbial population with bioremediation ability is one of the major factors (Das and Dash, 2014). Even though microorganismsplayagreatroleinbioremediation, our knowledge on the bioremediation potential of microorganisms is very limited (Dua et al., 2002; Hassan et al., 2016). Bioremediation is traditionally carried out in natural environment where many of the organisms have not been characterized. Only a limited number of microbes having bioremediation potential have been identified and characterized so far. This is also a crucial limiting factor of bioremediation (Singh and Ward, 2004). Microbial interactions (competition, succession, and predation) and the formation of toxic metabolites during bioremediation process may also be limitations (Boopathy, 2000).

\section{Substrate}

Availability of sufficient concentration of pollutant or toxic compounds that can be utilized by microorganisms for their nutrients or energy needs is one of the mostimportant factor that affects bioremediation potential (Boopathy, 2000; Singh and Ward, 2004). Even though microorganisms are present, if the toxicity of the pollutant is not tolerable by microorganisms, it will reduce their bioremediation potential (Singh and Ward, 2004). Chemical structure of contaminants is also an important factor. Sometimes, the compounds in pollutants may be non-biodegradable compounds such as, polymers, plastics etc. (Boopathy, 2000; Singh and Ward, 2004). "Chemical, physical, and biological" differences of the contaminated substance are also limitations of bioremediation (Das and Dash, 2014).

\section{Environmental Factors}

"Temperature, $\mathrm{pH}$, availability of oxygen" or any other electron acceptors (Boopathy, 2000; Singh and Ward, 2004; Das and Dash, 2014), redox potential (Eh), salinity (Aislabie 
and LloydJones, 1995; Boopathy, 2000), and moisture content (Aislabie and LloydJones, 1995; Singh et al., 2004; Das and Dash, 2014) are major environmental factors that directly affect the bioremediation potential. Either depletion of preferential substrates (Boopathy, 2000), the presence of readily available alternative nutrient sources, alternative electron acceptors in the environment, light quality and intensity can also be limitations for bioremediation potential (Aislabie and Lloyd Jones, 1995). For instance, Vasilyeva and Strijakova (2007) have discussed usage of the potential of microorganisms for bioremediation of soils and sediments contaminated with polychlorinated biphenyls under anaerobic and aerobic conditions. Under considered conditions, the remediation efficiency was higher in aerobic bioremediation. However, they have stated that contaminants can be noticeably decreased only under sequential anaerobic/aerobic treatment. It says that the effectiveness of the remediation process can vary depending on such different environmental conditions.

\section{Other Imitating factors}

In addition to the major limitations that occurred due to inappropriate bioavailability, substrate and environmental factors, some other limiting factors can also be identified. Among them, the Cost-benefit ratio may also be a limitation for the bioremediation process. (Varshney, 2019). Moreover, environmental disruptions may also become a limitation. For instance, when microorganisms are introduced to a natural land for the purpose of bioremediation, this can be disruptive to some other beneficial organisms due to the competition for nutrients or any other interactions among them. The organisms used in bioremediation may not always depend on the pollutant in obtaining required nutrients instead, they may tend to depend on other commonly available nutrient sources in the environment. Besides, the impact of genetically altered bioremediation organisms is even less understood. Hence, using such techniques may cause unnecessary environmental impacts. These facts can be considerable bottlenecks of in situ remediations. Time factor may also be another impotent aspect to be considered. This is because the microbial bioremediation process may take more time than that we expect (Singh, 2008). Moreover, in case the microbes used for the bioremediation produce secondary metabolites that can be more toxic or harmful than the original source contaminants, it can be another burning issue. Hence, investigating this area broadly before applying bioremediation techniques is greatly significant (Hassan et al., 2016).

\section{Popular Bioremediation Techniques in the World}

Even in the presence of many limiting factors, modern bioremediation techniques have achieved a substantial development making bioremediation an efficacious way of removing pollutants from the environment. As far as popular microbial bioremediation strategies in the world are concerned, there are mainly two types as In situ and Ex situ bioremediations (Boopathy, 2000; Iwamoto and Nasu, 2001; Das and Dash, 2014). In situ bioremediation is a method of applying bioremediation techniques at the contaminated site itself. In this technique, either taking scientific approaches to enhance the biodegradation ability of natural microflora or introducing a group of natural or genetically modified strains into the contaminated site is used. In Ex situ bioremediation process, contaminated materials are transported into a separate place where microbial bioremediation takes place under controlled conditions. In these strategies, many scientific and engineering technologies are used in optimization and control of microbial conversion of contaminants (Boopathy, 2000; Iwamoto and Nasu, 2001).

Bio-stimulation, Bioventing, Biosparging, Bioaugmentation, Biopiling, Composting, Bioreactors, Land farming like various popular bioremediation techniques are currently in practice in the world. In bio-stimulation, naturally occurring microorganisms are employed in degrading pollutants such as hydrocarbons, pesticides etc. Scientists have proven that bio-stimulation has a real potential as a technology for remediating contaminants in soil and water environments (Andreolli et al., 
2015; Aldas-Vargas et al., 2021). If the natural degradation does not happen or it is very slow, a stimulation of natural microbial degradation is achieved by supplying some nutrients such as, nitrogen, phosphorus and oxygen like electron acceptors required for the microbial activity (Boopathy, 2000; Iwamoto and Nasu, 2001). Bioaugmentation is also an In situ bioremediation techniques. This is more popular in remediation of pesticide contaminated soils (Pimmata et al., 2013; Cycoń et al., 2017; Raimondo et al., 2020a; Raimondo et al., 2020b). This technique differs from the above techniques as a group of natural or genetically engineered microbial strains (bacterial cultures) are introduced to the contaminated site to degrade contaminants (Das and Dash, 2014). According to Iwamoto and Nasu (2001), the bioaugmentation is an effective In situ bioremediation method to degrade very recalcitrant chemicals where most of the other bioremediation techniques are not successful. Boopathy (2000) says that bioaugmentation is abundantly used in both In situ and Ex situ systems. Moreover, some scientists have conducted research by combining both the above techniques together and proven that combination of above two strategies enhances the effectiveness of bioremediation (Pimmata et al., 2013; Raimondo et al., 2020a; Raimondo et al., 2020b). Biopiling is also another type of In situ bioremediation technique where excavated / tilled soil is mixed with soil amendments followed by forced aeration. In a basic biopile system, a treatment bed, an aeration system, an irrigation / nutrient system, and a leachate collection system are included and environmental factors such as, moisture, $\mathrm{pH}$, oxygen and nutrients are controlled within the biopile system. Irrigation / nutrient system is placed under soil whilst nutrients and air are passed by means of a positive or a negative pressure (Das and Dash, 2014). This method can also be identified as a successful and suiTable 0method for the bioremediation of pesticide contaminated soils (Parween et al., 2018; Varshney,2019).Composting is the most common Ex situ bioremediation method (Das and Dash, 2014). This is an aerobic, thermophilic treatment process in which contaminated materials and a bulking agent are mixed together in an aerated or a static pile followed by a microbial degradation (Boopathy, 2000). Typically the degradation process happens at an elevated temperature (in a range of $55^{\circ}-65^{\circ} \mathrm{C}$ ) resulted from the heat produced by the microorganisms themselves (Das and Dash, 2014). Composting has been mostly used in bioremediation of petroleum hydrocarbon contaminated soils (Jørgensen et al., 2000; Namkoong et al., 2002; Van Gestel et al., 2003). However, it can also be helpful in remediation of pesticide contaminants as well (Mena et al., 2003). Bioreactor is an Ex situ bioremediation practice in which contaminated medium is treated in a container or a vessel called a reactor (Boopathy, 2000; Das and Dash, 2014) and slurry or aquatic media are used. This technique is especially used to treat soil and water, pumped out of a contaminated site. A containment apparatus that forms three-phase (Solid, liquid and gas) mixing condition is used. Within this engineered system, the rate of microbial bioremediation of water soluble pollutants attached to soil is increased by enhancing the bio availability of the target contaminant (Das and Dash, 2014). This strategy can also be used in decontaminating pesticide contaminated soil and water. However, this method seems a much complicated and costly method when compared with above methods, since the bioremediation process cannot be performed in In situ conditions (Zapata et al., 2010; Suciu et al., 2013; Sun et al., 2020). Land farming is a "solid-phase remedial system" used to treat contaminated soils. This may be performed as Ex situ or In situ bioremediation practice (Boopathy, 2000). In this technique, contaminated wastes are deposited on the soil surface followed by degradation of contaminants by natural microbial metabolism (Marin et al., 2005; Lukić et al., 2017). One week later, wastes deposited on the soil surface are mixed with the top $1 \mathrm{~m}$ layer of soil and subsequently treated by aerating the that soil layer once a month (Marin et al., 2005). Soil environmental conditions are also controlled by monitoring moisture, $\mathrm{pH}$ and nutrients (Lukić et al., 2017).

Biosparging is an In situ bioremediation method which is somewhat similar to the bio stimulation. In this method, a pressurized air flow is injected below the ground water Table 0using air injection points having a small-diameter in order to enhance the oxygen concentration of water. As a consequence, biological degradation 
of contaminants by natural microflora involved in bioremediation is increased. (Das and Dash, 2014). Bioventing is another In situ bioremediation method which is used to stimulate natural microbial degradation of contaminants. In this technique, amount of oxygen sufficient for the sustainable microbial activity is provided using low air flow rates. This technique is also fairly similar to above two techniques. But generally in bioventing, the aeration of the unsaturated vadose zone is done where injection of air into the groundwater is done in biosparing to provide oxygen for groundwater remediation. (Boopathy, 2000; Das and Dash, 2014). These two strategies are commonly used in bioremediation of petroleum contaminated soil and ground water (Gray et al., 1996). Both of the above techniques are not generally employed in pesticide polluted locations (Parween et al., 2018).

\section{Recent Advancements in Bioremediation}

Since this field is still a developing area, it has taken the attention of most worldwide scientists. Hence, new improvements blend with new technological approaches are often observed. Most recently, scientists are focusing on advancements such as gene editing and system biology tools for pesticide bioremediation. In this context, scientists attempt to understand the genetics and biochemistry of the biodegradation process performed by natural microbes and using these data, try to develop a biodegradation network consists of all the datasets which aid in assisting the degradation and deterioration potential of microorganisms for bioremediation processes. This approach makes a path to develop remunerative systems by compiling the knowledge obtained by individual researchers. Moreover, worldwide, scientists are taking attempts in using recombinant DNA technology and gene-editing tools like CRISPR Cas, TALEN and ZFNs which can design genetically modified microbes having functional genes of interest for degradation of pollutants that are important for improved bioremediation (Jaiswal et al., 2019; Sharma and Shukla, 2020). Some scientists are researching using microbial glycoconjugates in the bioremediation of pollutants. Glycoconjugates amphiphilic compounds are synthesized onto the cell surface of the microorganism. These compounds act as a bridge between the microbial strains and soil, due to which the bioavailability of the pollutants increases and this can also be identified as a recent advancement in this field (Bhatt et al., 2021b). In addition to that, some ideas have been proposed to study various microbes when they live together as a community. Hence, scientists are currently researching the benefits of using microbial consortia in bio remediating pesticide contaminants beyond using an axenic culture in the process of bioremediation. Some studies have shown that using a mixed culture is more effective (Pimmata et al., 2013; Bhatt et al., 2021). For instance, Jariyal et al. (2018) have shown that a microbial consortia of three microorganisms (Brevibacterium frigoritolerans, Bacillus aerophilus and Pseudomonas fulva) could degrade organ phosphorus pesticide phorate, and the highest phorate removal (between 97.65 and $98.31 \%$ ) was found in soils inoculated with mixed cultures of all the three bacterial species. Another recently completed study has shown that a microbial consortium isolated from a (soil-straw; 1:1, v/v) biomixture can be used to successfully bioremediate a number of pesticides in a pesticide contaminated biobed (GóngoraEcheverría et al., 2020). Moreover, Some recent studies have proven that using a combination of two or more bioremediation strategies such as biostimulation, bioaugmentation etc. also enhances the effectiveness of bioremediation (Pimmata et al., 2013; Raimondo et al., 2020a; Raimondo et al., 2020b; Zhang et al., 2020).

\section{Soil Bacteria Capable of Degrading Pesticides}

Various soil bacterial strains have been identified with detoxification ability of pesticides and used successfully in bioremediation of pesticide contaminated sites. Ample studies have been conducted in this field worldwide. Some examples of soil bacteria with bioremediation potential are given bellow and this information is summarized in Table 01. 


\section{Table 01: Different soil bacteria species capable of degrading various pesticides}

\begin{tabular}{|c|c|c|}
\hline Bacterial species & Type of pesticide degraded & Reference \\
\hline \multirow{4}{*}{ Flavobacterium spp } & Diazinon, Parathion & (Sethunathan and Yoshida, 1973) \\
\hline & Diazinon & (Yasouri, 2006) \\
\hline & Pentachlorophenol & (Saber and Crawford, 1985) \\
\hline & Pentachlorophenol & (Briglia et al., 1990) \\
\hline Sphingobium spp. & Fenobucarb, Carbaryl & (Kim et al., 2014) \\
\hline \multirow{2}{*}{ Sphingobium fuliginis } & Diazinon, Parathion & (Kawahara et al., 2010) \\
\hline & Buprofezin & (Liu et al., 2015) \\
\hline \multirow[t]{2}{*}{ Sphingomonas $s p$} & Fenvalerate & (Yu et al., 2013) \\
\hline & Diazinon & (Yasouri, 2006) \\
\hline \multirow[t]{2}{*}{ Agrobacterium spp. } & $\begin{array}{c}\text { Methyl parathion } \\
\text { Phoxim, Methamidophos, } \\
\text { Chlorpyrifos, Carbofuran, } \\
\text { Deltamethrin }\end{array}$ & (Wang et al., 2012) \\
\hline & Atrazine & (Struthers et al., 1998) \\
\hline \multirow{3}{*}{ Pseudomonas spp. } & Diazinon & $\begin{array}{c}\text { (Yasouri, 2006) } \\
\text { (Cycoń et al., 2009) }\end{array}$ \\
\hline & Profenofos & (Malghani et al., 2009) \\
\hline & Methyl Parathion & (Chaudhry et al., 1988) \\
\hline
\end{tabular}

\begin{tabular}{ccc}
\hline Pseudomonas alcaligenes. & $\begin{array}{c}\text { Chlorpropham, Chlorobufam } \\
\text { Isopropyl-N-phenylcarbamate, } \\
\text { Methyl N-(3,4dichlorophenyl) } \\
\text { carbamate, propanil }\end{array}$ & (Marty and Vouges, 1987) \\
\hline Pseudomonas psychrophila & $\begin{array}{c}\text { Chlorpyrifos, Cypermethrin, } \\
\text { Endosulfan }\end{array}$ & (Naphade et al., 2012) \\
\hline Pseudomonas aeruginosa & $\begin{array}{c}\text { Chlorpyrifos, Cypermethrin, } \\
\text { Endosulfan }\end{array}$ & (Naphade et al., 2012) \\
\hline Pseudomonas frederiksbergensis & $\begin{array}{c}\text { Endosulfan, Chlorpyrifos, } \\
\text { Malathion }\end{array}$ & (Iqbal and Bartakke, 2014) \\
\hline Serratia spp. & Diazinon & (Cycoń et al., 2009) \\
\hline Serratia liquefaciens & Diazinon, Malathion & (Iqbal and Bartakke, 2014) \\
\hline Serratia marcescens & Diazinon, Chlorpyrifos & (Iqbal and Bartakke, 2014) \\
\hline Enterobacter spp. (Strain B-14) & Chlorpyrifos, Parathion, Diazinon, & (Singh et al., 2004) \\
\hline Burkholderia gladioli & Poumaphos, Isazofos & \\
\hline Burkholderia terrae & Dimetoate & (Malghani et al., 2009) \\
\hline Burkholderia cepacia & 2,4-dinitrophenol & (Iqbal and Bartakke, 2014) \\
\hline
\end{tabular}




\begin{tabular}{|c|c|c|}
\hline \multirow{3}{*}{ Novosphingobium spp } & $\begin{array}{l}\text { Fenobucarb, Carbaryl, } \\
\text { 2-sec-butylphenol }\end{array}$ & (Kim et al., 2014) \\
\hline & Carbofuran & (Yan et al., 2007) \\
\hline & $\begin{array}{l}\text { 2,4-dichlorophenoxyacetic } \\
\text { acid (2,4-D) }\end{array}$ & (Dai et al., 2015) \\
\hline Rhodococcus erythropolis & Endosulfan & (Kumar et al., 2007) \\
\hline Rhodococcus chlorophenolicus & Pentachlorophenol & (Briglia et al., 1990) \\
\hline Bacillus spp. & Mesotrione & (Batisson et al., 2009). \\
\hline Bacillus spp. & Triazophos & (Tang and You, 2012). \\
\hline Bacillus spp. & Methylparathion & (Sreenivasulu and Aparna, 2001) \\
\hline Bacillus pumilus & $\begin{array}{l}\text { Malathion, Dimetoate, } \\
\text { Chlorpyrifos }\end{array}$ & (Iqbal and Bartakke, 2014) \\
\hline $\begin{array}{l}\text { Stenotrophomonas } \\
\text { maltophilia }\end{array}$ & Endosulfan & (Kumar et al., 2007) \\
\hline Acinetobacter radioresistens & Chlorpyrifos & (Iqbal and Bartakke, 2014) \\
\hline Klebsiella spp. & Chlorpyrifos & $\begin{array}{l}\text { (Ghanem et al., 2007) } \\
\text { (John et al., 2018) }\end{array}$ \\
\hline Klebsiella spp. & Triazophos & (Wang et al., 2005) \\
\hline Klebsiella pneumoniae & Endosulfan & (Kwon et al., 2002) \\
\hline Klebsiella oxytoca & Endosulfan & (Kwon et al., 2005) \\
\hline Arthrobacter spp. & Carbaryl & (Sato et al., 1999) \\
\hline Arthrobacter spp. & Diuron & (Widehem et al., 2002) \\
\hline Arthrobacter spp. & Atrazine & (Getenga et al., 2009) \\
\hline Arthrobacter spp. & Terbuthylazine & (Getenga et al., 2009) \\
\hline Lysobacter spp. & Chlorothalonil & (Wang et al., 2011) \\
\hline Stenotrophomonas spp. & Chlorothalonil & (ZHANG et al., 2014) \\
\hline Stenotrophomonas spp. & $\begin{array}{l}\text { O,O-dialkyl phosphorothioate } \\
\text { O,O-dialkyl phosphate }\end{array}$ & (Deng et al., 2015) \\
\hline Stenotrophomonas maltophilia & Chlorpyrifos & (Dubey and Fulekar, 2012) \\
\hline Stenotrophomonas maltophilia & Methomyl & (Mohamed, 2009) \\
\hline Sphingomonas melonis & Methomyl & (Tatar et al., 2020) \\
\hline Ochrobactrum thiophenivorans & Methomyl & (Tatar et al., 2020) \\
\hline
\end{tabular}

\section{Pseudomonas spp.}

Chaudhry et al. (1988) have isolated two mixed bacterial cultures that are able to utilize methyl parathion and parathion as the sole carbon source. One member of this mixed culture has been identified as Pseudomonas spp. , P. frederiksbergensis has also been isolated using soil collected from agricultural lands in India having capability of degrading endosulfan, chlorpyrifos and malathion (Iqbal and Bartakke, 2014). It has also revealed that Pseudomonas spp. can degrade diazinon for their carbon, phosphorous and/or energy source (Yasouri, 2006; Cycoń et al., 2009). A study conducted in Iran has disclosed that diazinon degradation ability of Pseudomonas is a plasmid mediated process and three endogenous plasmids were identified (Yasouri, 2006). Cycoń et al. (2009) have also isolated and identified three bacterial strains involved in bioremediation of diazinon in Soil. Of the three isolates, Pseudomonas spp. was capable of growing in mineral salt medium that included $50 \mathrm{ppm}$ of diazinon as the 
sole carbon source. Moreover, their studies on biodegradation ability of bacteria in sterilized soil have identified that isolated organisms and their consortium were having an efficient insecticide degrading ability (100 $\mathrm{mg} \mathrm{kg}^{-1}$ soil). In another study conducted in China, biodegradation of profenofos-contaminated soil using a bacterial culture isolated from soil has been shown. The isolate has shown $96 \%$ similarity to the $16 \mathrm{~S}$ rRNA gene of P. putida. Degradation of profenofos by that isolate has been $96.06 \%$ within 25 days. (Malghani et al., 2009). Naphade et al. (2012) have isolated five bacterial strains from garden soils from Kalyan city, Maharashtra state in India, that tolerated high concentrations of chlorpyrifos, cypermethrin and endosulfan. Of five isolates, two Pseudomonas spp. were identified as $P$. psychrophila and P. aeruginosa. Among them, P. psychrophila has shown resistance to 10000 ppm, $8000 \mathrm{ppm}$ and $400 \mathrm{ppm}$ concentrations of chlorpyrifos, cypermethrin and endosulfan, respectively. Whereas, $P$. aeruginosa has shown resistance to $15000 \mathrm{ppm}, 12000 \mathrm{ppm}$ and 19000 ppm concentrations of chlorpyrifos, cypermethrin and endosulfan, respectively. Moreover, they have isolated plasmids from isolated bacteria and transferred into Escherichia coli cells and tested for bioremediation ability of those $E$. coli cells. By observing their bioremediation ability, they have inferred that the resistant traits observed are plasmid borne. This also supports the argument that Pseudomonas spp. is having an ability to degrade pesticides. It supports the finding of Yasouri (2006). Furthermore, pesticide degrading enzymes have been isolated from Pseudomonas spp. For instance, phenyl carbamate degrading enzyme has been isolated from $P$. alcaligenes isolated from soil (Marty and Vouges, 1987). They have shown that the purified enzyme could degrade a number of phenyl carbamate herbicides (chlorpropham, chlorobufam, isopropyl-N-phenylcarbamate and methyl N-(3,4-dichlorophenyl) carbamate) and propanil. This study convinces that pesticide degradation mechanism by Pseudomonas spp. is an enzymatic process (Marty and Vouges, 1987). All the above findings together testify the potential of using Pseudomonas spp. in bioremediation of some common pesticides accumulated in the environment.

\section{Agrobacterium spp.}

Bioremediation ability of the soil bacterium, Agrobacterium radiobacter $\mathrm{J} 14 \mathrm{a}$, has been examined for the herbicide atrazine in different cultural conditions. Atrazine mineralization of $94 \%$ out of $50 \mathrm{mg} \mathrm{mL}^{-1}$ has been observed in 72 hours with a concurrent enhancement in population size of bacterium from $7.9 \times 10^{5}$ to $5.0 \times 10^{7}$ cells $\mathrm{mL}^{-1}$ in a medium provided with sucrose and citrate as sole carbon sources but without a nitrogen source. Approximately, $30 \%$ of carbon has also been incorporated into bacterial biomass. Bacterium has also grown in a medium which does not include additional carbon and nitrogen sources. Also, in that situation, the degradation of atrazine has been observed but, cell number has not been increased. However, that result proves that $A$. radiobacter $\mathrm{J} 14 \mathrm{a}$ can utilize atrazine as the sole carbon and nitrogen source. They have further identified deethylatrazine, deethyl-hydroxyatrazine and hydroxyatrazine as the metabolites produced by atrazine metabolism by the bacterium. Moreover, they have inoculated $A$. radiobacter $\mathrm{J} 14$ a cells into soil treated with atrazin (50 and $200 \mu \mathrm{g}$ atrazin $\mathrm{g}^{-1}$ soil) with a low indigenous Atrazine-degrading population. Two to five time higher mineralization has been observed when compared with non-inoculated soil (Struthers et al., 1998). Biodegradation ability of a newly isolated Agrobacterium spp. (Strain Yw 12) For the pesticides methyl parathion and p-nitrophenol have been demonstrated (Wang et al., 2011). They have proven that the isolated strain has a broad degradation capacity for a number of pesticides. Strain Yw 12 isolated from activated sludge has been able to entirely degrade and consume this pesticide as the sole carbon, phosphorus and energy sources essential for its growth in a basic salt medium. Furthermore, strain Yw 12 was able to degrade and utilize $p$-nitrophenol as the sole carbon and energy source. They have revealed that, the strain Yw 12 could completely degrade $50 \mathrm{mg} \mathrm{L^{-1 }}$ of methyl parathion within 2 hours and the degradation product $p$-Nitrophenol (PNP) was also degraded within 6 hours. Moreover, they have mentioned that the strain could also degrade "chlorpyrifos, methamidophos, deltamethrin, carbofuran, phoxim, and atrazine" proving the results of (Struthers et al., 1998). An enzymatic 
analysis has revealed that an intracellular enzyme was responsible for methyl parathion degrading ability of the strain Yw 12. (Wang et al., 2012). Yasouri (2006) has also convinced that the diazinon degradation ability of Agrobacterium spp. is a plasmid mediated process.

\section{Flavobacterium spp.}

Three bacterial species having the ability to utilize diazinon as a sole carbon, phosphorus and energy source have been isolated from an enrichment culture. Of the three isolates, one has been identified as Flavobacterium spp. The degradation was plasmid mediated (Yasouri, 2006). Saber and Crawford (1985) have isolated a number of bacterial strains that can mineralize 100 to $200 \mathrm{ppm}$ of pentachlorophenol by selective enrichment from pentachlorophenol contaminated soil in Navarre. All the isolated strains have been identified to be Flavobacterium spp. They have further revealed that, all the strains could metabolize pentachlorophenol as a sole source of carbon and energy releasing $73-83 \%$ of $\mathrm{CO}_{2}$ out of all carbon in the form of pentachlorophenol with a full liberation of chlorine as chloride. Briglia et al. (1990) have tested the survival of pentachlorophenol (PCP) degrading Flavobacterium spp. in natural soil in Finland. According to their results, Flavobacterium spp. has reduced the initial amount of PCP $750 \mathrm{mg} \mathrm{kg}^{-1}$ in soil to $510 \mathrm{mg} \mathrm{kg}^{-1}$. But in the presence of additionally supplemented carbon sources, this degrading ability has been dramatically decreased. Furthermore, they have mentioned that the PCP degrading ability of Flavobacterium spp. has declined after 60 days in natural soil, unlike in liquid cultures.

\section{Sphingobium spp.}

Abacterium having capability ofdecomposing and utilizing diazinon which is an organophosphate insecticide, as the sole carbon source in a mineral medium has been isolated from paddy water in Philippines in 1971 (Sethunathan and Yoshida, 1973). The isolate has first hydrolyzed diazinon to 2-isopropyl-6-methyl-4-hydroxy-pyrimidine followed by conversion to $\mathrm{CO}_{2}$. The same isolate has also converted parathion to p-nitrophenol. The researchers have identified the bacterium as a Flavobacterium spp. and deposited with the American Type Culture Collection (ATCC 27551) (Sethunathan and Yoshida, 1973). Later on, Kawahara et al. (2010) have reclassified this ATCC 27551 as Sphingobium fuliginis by a phylogenetic analysis of $16 \mathrm{~S}$ rRNA gene. Mulbry and Karns (1989) have conducted a study using this ATCC 27551 and two other strains and revealed that organophosphorus hydrolase enzyme mediated the diazinon degradation process. Mulbry et al. (1986) have also revealed that a size of $43 \mathrm{~kb}$ plasmid is associated with the production of parathion hydrolase in this bacterium. Liu et al. (2015) have also performed an experiment to figure out the feasibility of remedying the contaminations of buprofezing which is a commonly used insecticide, by using a Sphingobium sp. (LY-6) isolated from soils. In their experiment, they have shown that, buprofezin is effectively degraded by Sphingobium spp. However, in the later part of the incubation period, a decrease in bacterial abundance has been observed suggesting that buprofezin possesses a negative effect on bacteria. Kim et al. (2014) have isolated and identified a number of Sphingobium spp. namely, S. lactosutens, S. chungbukense, S. lucknowense, S. chlorophenolicum, S. herbicidovoran from paddy land soil which were able to effectively degrade two carbamate pesticides namely fenobucarb and carbaryl.

\section{Sphingomonas spp.}

Yu et al. (2013) have isolated a bacterial strain that can degrade fenvalerate which is one of the most versatile synthetic pyrethroid insecticide from contaminated sludge. The strain has been identified to be Sphingomonas spp. by phylogenetic analysis of $16 \mathrm{~S}$ rRNA gene sequence.

\section{Serratia spp.}

Six bacterial strains have been isolated from soil in India. Two among six isolates have been identified as Serratia liquefaciens and 
S. marcescens. Degradation potential of each isolate has been tested for nine pesticides. Out of them, Serratia spp. has shown positive results for 5 pesticides. S. liquefaciens has shown 51\% degradation of diazinon and $11 \%$ marginal degradation of malathion. S. marcescens has shown $34 \%$ partial degradation of diazinon and 8 $\%$, and $1 \%$ marginal degradation of chlorpyrifos, and methyl parathion respectively (Iqbal and Bartakke, 2014). In another study conducted in Poland, three bacterial strains have been screened for the potential of diazinon degradation. Of three strains isolated from soil, two Serratia spp. have been identified as $S$. liquefaciens and S. marcescens. Both of the isolates were capable of growing in mineral salt medium that includes diazinon $\left(50 \mathrm{mg} \mathrm{L}^{-1}\right)$ as the sole carbon source and $80-92 \%$ of the initial concentration has been degraded. Moreover, they have observed an accelerated degradation than the initial status when the medium was supplemented with glucose. (Cycon et al., 2009). The results of this study support the finding of Iqbal and Bartakke (2014) while a higher diazinon degradation potential has been observed.

\section{Enterobacter spp.}

A bacterial strain (Strain B-14) has been isolated from soil in Australia and its ability to mineralize chlorpyrifos has been examined. That strain has shown a great similarity to the order Enterobacteriales and closest to Enterobacter asburiae. The isolate has utilized chlorpyrifos as the sole source of carbon and phosphorus by more than $40 \%$ of degradation chlorpyrifos within 48 hours. In the process of degradation, diethylthiophospshate (DETP) and 3, 5, 6-trichloro-2 pyridinol have been produced by hydrolyzing chlorpyrifos followed by the utilization of DETP for growth and energy. But, adding other carbon sources (glucose and succinate) have shown a slowdown in the initial degradation rate of chlorpyrifos. However, the strain has degraded not only chlorpyrifos, but also some other DETP containing organophosphates namely, parathion, diazinon, coumaphos, and isazofos when provided as the sole source of carbon and phosphorus. They have further tested the bioremediation potential of the strain B-14 by addition to field soils and more rapid rate of chlorpyrifos degradation has been observed than the degradation rate of indigenous microbe populations (Singh et al., 2004).

\section{Burkholderia spp.}

Iqbal and Bartakke (2014) have identified six pesticide degrading bacterial strains in their study conducted in India. Of six isolates, Burkholderia gladioli has shown a marginal degradation of dimethoate by $3 \%$. However, in another study conducted in China, B. gladioli has degraded 99.37\% profenofos within 25 days. (Malghani et al., 2009). In Japan, a bacterium isolated from agricultural soil having pesticide contaminations has utilized 2,4-dinitrophenol as the sole source of carbon and nitrogen. The strain has been identified as B. terrae. (Iwaki et al., 2007). Smith and Beadle (2008) has also proven that $B$. cepacia has a 2,4-dichlorophenoxyacetate $(2,4-$ D) degrading ability.

\section{Novosphingobium spp.}

In a study conducted in South Korea. Novosphingobium mathurense and $N$. taihuense have been isolated from a paddy land soil and identified as "carbaryl, fenobucarb and 2-secbutylphenol" degraders. The isolates grown on fenobucarb have entirely degraded $100 \mu \mathrm{gmL}^{-1}$ of the pesticide within 27 hours, and the bacterial cell density has gradually increased in proportion to fenobucarb degradation. Both isolates have shown almost the same degradation and growth pattern. (Kim et al., 2014). In another study conducted in China, Novosphingobium spp. strain FND-3 capable of degrading carbofuran has been isolated and characterized. The isolate has shown a higher carbofuran degrading rate of $28.6 \mathrm{mgL}^{-1}$ per hour in mineral salts medium with $100 \mathrm{mgL}^{-1}$ carbofuran (Yan et al., 2007). Dai et al. (2015) have investigated the bioremediation potential of Novosphingobium spp. (strain DY4) for heavily polluted soil with 2,4-dichlorophenoxyacetic acid (2,4-D). They have observed more than 50 and $95 \%$ of $2,4-\mathrm{D}$ degradation in bioaugmented soil (treated with $200 \mathrm{mgkg}^{-1}$ 2,4-D) in 3-4 and 
5-7 days, respectively. Moreover, the strain DY4 has shown a positive PCR amplification with the primers for $T f d A \alpha$ gene which is responsible for 2,4-D degradation.

\section{Rhodococcus spp.}

A group of scientists have conducted a study on "Survival of pentachlorophenol (PCP)-degrading bacteria Rhodococcus chlorophenolicus PCP-1 in natural soil" in Finland. They have tested the PCP degradation capacity of the strain by introducing into natural soil at a concentration of $10^{9}$ cells $g^{-1}$ soil. $R$. chlorophenolicus has induced PCP degrading activity in soil. $R$. chlorophenolicus has degraded PCP in soil at a mean rate of $3.7 \mathrm{mg}$ $\mathrm{kg}^{-1}$ soil per day. Moreover, they have followed the survival of the strain for 200 days and found that PCP mineralizing activity has remained relatively constant throughout the considered period of time. (Briglia et al., 1990). In another study conducted in India, 73\% - 81\% respectively $\alpha$ and $\beta$ endosulfan degrading potential has been observed within 15 days by a mixed culture isolated form pesticide contaminated soil. By phylogenetic analysis, they have revealed that, $R$. erythropolis has given a vast contribution for the degradation by the mixed culture. When studying the degradation ability of $R$. chlorophenolicus as a pure culture, out of $100 \mathrm{mgL}^{-1}$ initial concentration, $24 \%$ and $26 \%$ degradations of $\alpha$ and $\beta$ endosulfan respectively, have been observed within 15 days after inoculation (Kumar et al., 2007).

\section{Bacillus spp.}

A Bacillus sp. has been isolated from soil in France and identified to be able to completely and rapidly bio-transform an herbicide called mesotrione. The capacity of each isolate to degrade 0.1-1 $\mathrm{mM}$ mesotrione has been investigated. The Bacillus sp. has shown a complete degradation of mesotrione after maximum 50 hours of incubation (Batisson et al., 2009). A new triazophos-degrading Bacillus sp. has been isolated from sewage sludge in a wastewater treating system of an organophosphorus pesticide producing company in China. The isolate was capable of hydrolyzing insecticide triazophos and degrading $98.5 \%$ of triazophos $\left(100 \mathrm{mg} \mathrm{L}^{-1}\right)$ in the medium within 5 days, when fed with additional nutrients like "yeast extract, peptone and glucose". They have further observed that an intracellular enzyme appeared to be responsible for the degradation. (Tang and You, 2012). Methyl parathion bioremediation ability of Bacillus sp. isolated from a cotton field soil in India has been studied by analyzing degradation ability of 100, 200, $400,800,1000 \mu M$ concentrations of methyl parathion. Isolated Bacillus sp. has taken 24, 36, 66 and 102 hours to completely degrade 100, 200, 400 and $800 \mu M$ concentrations respectively. However, no degradation has been observed in $1000 \mu M$ concentration. It proves that higher concentration of methyl parathion appeared to be toxic to Bacillus sp. This results show that when the pesticide concentration is increased, the bioremediation ability of Bacillus spp. can be lost (Sreenivasulu and Aparna, 2001). Iqbal and Bartakke (2014) have identified B. pumilus to be capable of degrading malathion and dimethoate with $45 \%$ and $37 \%$ respectively. Moreover, the same bacterium was also able to partially degrade chlorpyrifos by $15 \%$.

\section{Klebsiella spp.}

Klebsiella spp. capable of degrading chlorpyrifos has been isolated from sludge samples collected from a wastewater treatment plant in Syria. Isolate has found to break down $92 \%$ of chlorpyrifos within four days in a poor mineral medium supplemented with chlorpyrifos as the sole carbon source at the concentration of 13.9 $g L^{-1}$. However, in the sludge sample itself the degradation rate was as lower as $46 \%$ unlike in mineral medium. (Ghanem et al., 2007). In order to evaluate the In situ biodegradation ability of Klebsiella spp., John et al. (2018) have conducted an experiment using a Klebsiella $s p$. isolated from pesticide applied soil. By an In situ bioremediation study, they have provided evidences on the potential of using Klebsiella spp. for bioremediation of chlorpyrifos-contaminated soil. Wang et al. (2005) have isolated a triazophos degrading Klebsoella spp. from soil having a long-term exposure to triazophos. When supplied 
as the sole nitrogen source, the isolate has more effectively utilized triazophos. Based on the intermediates of triazophos metabolism, they have determined that the degradation process occurred through a hydrolysis mechanism. Moreover, one of the intermediate (1-phenyl-3-hydroxy1,2,4-triazole) has also been mineralized by the isolate. No inhibitory effect has been observed even in a higher triazophos concentration as high as $1000 \mathrm{mg} \mathrm{L}^{-1 .}$. It shows the great potential of using Klebsiella spp. for bioremediation of triazophos even at high concentrations. Some other evidences are also found to prove the biodegradation potential of Klebsiella spp. by unveiling the endosulfan degrading potential. Kwon etal. (2002) have proven the biodegradation potential of endosulfan by K. pneumonia in their study by using the pesticide as the sole carbon and energy sources. This bacterium was able to degrade endosulfan (8.72 $\left.\mu \mathrm{g} m L^{-1}\right)$ within one day. However, at the concentration of 93.9 $\mu g m L^{-1}$, the degradation process has taken 10 days. However, this isolate has failed to degrade endosulfan sulfate which is a toxic metabolite generated during endosulfan degrading process. In contrast, Kwon et al. (2005) have confirmed the high potential of using Klebsiella spp. in biodegrading endosulfan by giving another example having ability to biodegrade endosulfan without formation of endosulfan sulfate. In that study, they have revealed that $K$. oxytoca isolated from endosulfan-polluted soils can effectively biodegrade both endosulfan and endosulfan sulfate.

\section{Arthrobacter spp.}

From forest soil, Sato et al. (1999) have isolated two Arthrobacter spp. that rapidly degrade carbaryl. Both isolates have been identified as novel species. Both strains have been able to degrade $50 \mu \mathrm{g} \mathrm{L}^{-1}$ carbaryl in a mineral salt medium within a day. 1-naphthol has been identified as the major degradation metabolite whereas, 1,4-naphthalenedione and 1,4-naphtbalenediol have been identified as minor metabolites.

\section{CONCLUSIONS AND FUTURE PERSPECTIVES}

Bioremediation of pesticides by microbes provides plenty of advantages including low input cost, long period removal process, an easy and simple requirement for equipment and space, providing economically effective environmental protection. It can play a greater role in mitigating the potential risk posed by pesticides to the natural echo system without losing the production and productivity in agriculture. Under this context, a number of studies have been conducted worldwide. However, the environmental pollution and health hazards caused by pesticides still remain a burning issue. This might be due to the lack of identified versatile microorganisms that can be used for detoxifying, a variety of different pesticides. Moreover, genetically modified microorganisms can offer a new hope in this regard. Furthermore, there can be a plenty of unidentified microorganisms with various pesticides detoxification capabilities. Hence, conducting further studies in order to identify new microorganisms with such capabilities in different geographical regions of the world is timely important.

\section{ACKNOWLEDGEMENT}

This work was funded by the "Accelerating Higher Education Expansion and Development" (AHEAD) project of the World Bank (Grant number: AHEAD/DOR/STEM/33).

\section{REFERENCES}

Aislabie, J. and lloydjones, G. (1995). A review of bacterial-degradation of pesticides. Soil Research, 33, 925-942. https://doi.org/10.1071/SR9950925

Akan, J., Mohammed, Z., Jafiya, L. and Ogugbuaja, V. (2013). Organochlorine pesticide residues in fish samples from Alau Dam, Borno State, North Eastern Nigeria. J Environ Anal Toxicol, 3. 
Akashe, M. M., Pawade, U. V. and Nikam, A. V. (2018). Classification of Pesticides: A Review. International Journal of Research in Ayurveda and Pharmacy, 9, 144-150. https://doi. org/10.7897/2277-4343.094131

Aldas-Vargas, A., Van der vooren, T., Rijnaarts, H. H. and Sutton, N. B. (2021). Biostimulation is a valuable tool to assess pesticide biodegradation capacity of groundwater microorganisms. Chemosphere, 280, 130793. https://doi.org/10.1016/j.chemosphere.2021.130793

Almeida, L. G. D., Moraes, L. A. B. D., Trigo, J. R., Omoto, C. and Consoli, F. L. (2017). The gut microbiota of insecticide-resistant insects houses insecticide-degrading bacteria: A potential source for biotechnological exploitation. PloS one, 12, e0174754. https://doi.org/10.1371/ journal.pone.0174754

Andreolli, M., Lampis, S., Brignoli, P. and Vallini, G. (2015). Bioaugmentation and biostimulation as strategies for the bioremediation of a burned woodland soil contaminated by toxic hydrocarbons: a comparative study. Journal of environmental management, 153, 121-131. https://doi. org/10.1016/j.jenvman.2015.02.007

Batisson, I., Crouzet, O., Besse-Hoggan, P., Sancelme, M., Mangot, J.-F., Mallet, C. and Bohatier, J. (2009). Isolation and characterization of mesotrione-degrading Bacillus sp. from soil. Environmental Pollution, 157, 1195-1201. https://doi.org/10.1016/j.envpol.2008.12.009

Bhardwaj, A., Rajput, R. and Misra, K. (2019). Status of arsenic remediation in India. Advances in Water Purification Techniques. Elsevier. https://doi.org/10.1016/B978-0-12-814790-0.00009-0

Bhatt, P., Bhatt, K., Sharma, A., Zhang, W., Mishra, S. and Chen, S. (2021). Biotechnological basis of microbial consortia for the removal of pesticides from the environment. Critical Reviews in Biotechnology, 41, 317-338.https://doi.org/10.1080/07388551.2020.1853032

Binukumar, B. and Gill, K. D. (2011). Chronic exposure to pesticides-neurological, neurobehavioral and molecular targets of neurotoxicity. Pesticides in the modern world-Effects of pesticides exposure, 3-20.

Bollag, J.-M. and Liu, S.-Y. (1990). Biological transformation processes of pesticides. Pesticides in the soil environment: processes, impacts and modeling, 2, 169-211. https://doi.org/10.2136/ sssabookser2.c6

Boopathy, R. (2000). Factors limiting bioremediation technologies. Bioresource technology, 74, 6367. https://doi.org/10.1016/S0960-8524(99)00144-3

Briglia, M., Nurmiaho-Lassila, E., Vallini, G. and Salkinoja-Salonen, M. (1990). The survival of the pentachlorophenol-degrading Rhodococcus chlorophenolicus PCP-1 and Flavobacterium sp. in natural soil. Biodegradation, 1, 273-281.https://doi.org/10.1007/BF00119764

Chaudhry, G., Ali, A. and Wheeler, W. (1988). Isolation of a methyl parathion-degrading Pseudomonas sp. that possesses DNA homologous to the opd gene from a Flavobacterium sp. Appl. Environ. Microbiol., 54, 288-293. https://doi.org/10.1128/aem.54.2.288-293.1988

Chen, W. and Mulchandani, A. (1998). The use of live biocatalysts for pesticide detoxification. Trends in biotechnology, 16, 71-76. https://doi.org/10.1016/S0167-7799(97)01160-8

Cooper, J. and Dobson, H. (2007). The benefits of pesticides to mankind and the environment. Crop Protection, 26, 1337-1348. https://doi.org/10.1016/j.cropro.2007.03.022

Council_on_scientific_affairs (1997). Educational and informational strategies to reduce pesticide risks. Council on Scientific Affairs. Prev Med. 1997/03/01 ed. 
Curl, C. L., Fenske, R. A., Kissel, J. C., Shirai, J. H., Moate, T. F., Griffith, W., Coronado, G. and Thompson, B. (2002). Evaluation of take-home organophosphorus pesticide exposure among agricultural workers and their children. Environmental health perspectives, 110, A787-A792. https://doi.org/10.1289/ehp.021100787

Cycoń, M., Mrozik, A. and Piotrowska-Seget, Z. (2017). Bioaugmentation as a strategy for the remediation of pesticide-polluted soil: A review. Chemosphere, 172, 52-71.https://doi. org/10.1016/j.chemosphere.2016.12.129

Cycoń, M., Wójcik, M. and Piotrowska-Seget, Z. (2009). Biodegradation of the organophosphorus insecticide diazinon by Serratia sp. and Pseudomonas sp. and their use in bioremediation of contaminated soil. Chemosphere, 76, 494-501. https://doi.org/10.1016/j. chemosphere.2009.03.023

Dai, Y., Li, N., Zhao, Q. and Xie, S. (2015). Bioremediation using Novosphingobium strain DY4 for 2, 4-dichlorophenoxyacetic acid-contaminated soil and impact on microbial community structure. Biodegradation, 26, 161-170. https://doi.org/10.1007/s10532-015-9724-7

Darko, G., Akoto, O. and Oppong, C. (2008). Persistent organochlorine pesticide residues in fish, sediments and water from Lake Bosomtwi, Ghana. Chemosphere, 72, 21-24.https://doi. org/10.1016/j.chemosphere.2008.02.052

Das, S. and Dash, H. R. (2014). Microbial bioremediation: A potential tool for restoration of contaminated areas. Microbial biodegradation and bioremediation. Elsevier.

De, A., Bose, R., Kumar, A. and Mozumdar, S. (2014). Worldwide pesticide use. Targeted delivery of pesticides using biodegradable polymeric nanoparticles. Springer. https://doi.org/10.1007/97881-322-1689-6

Deng, S., Chen, Y., Wang, D., Shi, T., Wu, X., Ma, X., Li, X., Hua, R., Tang, X. and Li, Q. X. (2015). Rapid biodegradation of organophosphorus pesticides by Stenotrophomonas sp. G1. Journal of hazardous materials, 297, 17-24.https://doi.org/10.1016/j.jhazmat.2015.04.052

Dua, M., Singh, A., Sethunathan, N.and Johri, A. (2002). Biotechnology and bioremediation: successes and limitations. Applied microbiology and biotechnology, 59, 143-152. https://doi.org/10.1007/ s00253-002-1024-6

Dubey, K. K. and Fulekar, M. (2012). Chlorpyrifos bioremediation in Pennisetum rhizosphere by a novel potential degrader Stenotrophomonas maltophilia MHF ENV20. World Journal of Microbiology and Biotechnology, 28, 1715-1725. https://doi.org/10.1007/s11274-011-0982-1

Fao. (2020). Pesticides use [Online]. Food and agriculture organization of the united nation. Available: http://www.fao.org/faostat/en/\#data/RP/visualize [Accessed 04 September 2020 2020].

Flexner, J. L., Lighthart, B. and Croft, B. (1986). The effects of microbial pesticides on non-target, beneficial arthropods. Agriculture, ecosystems \& environment, 16, 203-254. https://doi. org/10.1016/0167-8809(86)90005-8

Gavrilescu, M. (2005). Fate of pesticides in the environment and its bioremediation. Engineering in Life Sciences, 5, 497-526. https://doi.org/10.1002/elsc.200520098

Geetha, M. and Fulekar, M. (2008). Bioremediation of pesticides in surface soil treatment unit using microbial consortia. African Journal of Environmental Science and Technology, 2, 036-045.

Getenga, Z., Dörfler, U., Iwobi, A., Schmid, M. and Schroll, R. (2009). Atrazine and terbuthylazine mineralization by an Arthrobacter sp. isolated from a sugarcane-cultivated soil in Kenya. Chemosphere, 77, 534-539. https://doi.org/10.1016/j.chemosphere.2009.07.031 
Ghanem, I., Orfi, M. and Shamma, M. (2007). Biodegradation of chlorphyrifos byKlebsiella sp. isolated from an activated sludge sample of waste water treatment plant in damascus. Folia Microbiologica, 52, 423-427. https://doi.org/10.1007/BF02932098

Gilden, R. C., Huffling, K. and Sattler, B. (2010). Pesticides and health risks. J Obstet Gynecol Neonatal Nurs, 39, 103-110. https://doi.org/10.1111/j.1552-6909.2009.01092.x

Góngora-Echeverría, V. R., García-Escalante, R., Rojas-Herrera, R., Giácoman-Vallejos, G. and PonceCaballero, C. (2020). Pesticide bioremediation in liquid media using a microbial consortium and bacteria-pure strains isolated from a biomixture used in agricultural areas. Ecotoxicology and Environmental Safety, 200, 110734. https://doi.org/10.1016/j.ecoenv.2020.110734

Gray, A., Brown, A., Moore, B. and Payne, R. Respiration testing for bioventing and biosparging remediation of petroleum contaminated soil and ground water. The sixth West Coast conference on contaminated soils and groundwater: Analysis, fate, environmental and public health effects, and remediation. Part 3, 1996.

Gupta, S. and Singh, D. (2017). Role of genetically modified microorganisms in heavy metal bioremediation. Advances in Environmental Biotechnology. Springer. https://doi. org/10.1007/978-981-10-4041-2_12

Hassan, i., Mohamedelhassan, e., Yanful, e. K. \& Yuan, z.-C. (2016). A review article: Electrokinetic bioremediation current knowledge and new prospects. Advances in Microbiology, 6, 57. https:// doi.org/10.4236/aim.2016.61006

Heshmati, A., Komacki, H., Nazemi, F. and Khaneghah, A. M. (2020). Persistence and dissipation behavior of pesticide residues in parsley (Petroselinum crispum) under field conditions. Quality Assurance and Safety of Crops \& Foods, 12, 55-65. https://doi.org/10.15586/qas.v12i3.755

Hutchinson, S. L., Schwab, A. and Banks, M. (2001). Phytoremediation of aged petroleum sludge: effect of irrigation techniques and scheduling. Journal of environmental quality, 30, 1516-1522. https://doi.org/10.2134/jeq2001.3051516x

Iqbal, M. A. and Bartakke, K. (2014). Isolation of pesticide degrading microorganisms from soil. $A d v$. Biores, 5, 164-168. https://doi.org/10.15515/abr.0976-4585.5.4.164168

Iwaki, H., Abe, K. and Hasegawa, Y. (2007). Isolation and characterization of a new 2, 4-dinitrophenoldegrading bacterium Burkholderia sp. strain KU-46 and its degradation pathway. FEMS microbiology letters, 274, 112-117. https://doi.org/10.1111/j.1574-6968.2007.00816.x

Iwamoto, T. and Nasu, M. (2001). Current bioremediation practice and perspective. Journal of bioscience and bioengineering, 92, 1-8.https://doi.org/10.1016/S1389-1723(01)80190-0

Jafari, M., Danesh, Y. R., Goltapeh, E. M. and Varma, A. (2013). Bioremediation and genetically modified organisms. Fungi as bioremediators. Springer. https://doi.org/10.1007/978-3-64233811-3_19

Jariyal, M., Jindal, V., Mandal, K., Gupta, V. K. and Singh, B. (2018). Bioremediation of organophosphorus pesticide phorate in soil by microbial consortia. Ecotoxicology and environmental safety, 159, 310-316. https://doi.org/10.1016/j.ecoenv.2018.04.063

Jeyaratnam, J. (1985). Health problems of pesticide usage in the Third World. British journal of industrial medicine, 42, 505. https://doi.org/10.1136/oem.42.8.505

John, E. M., Varghese, E. M., Krishnasree, N. and Jisha, M. (2018). In situ bioremediation of chlorpyrifos by Klebsiella sp. isolated from pesticide contaminated agricultural soil. International Journal of Current Microbiology and Applied Sciences, 7, 1418-1429. https://doi. org/10.20546/ijcmas.2018.703.170 
Johnson, L. and Talbot, H. (1983). Detoxification of pesticides by microbial enzymes. Experientia, 39, 1236-1246. https://doi.org/10.1007/BF01990361

Jørgensen, K., Puustinen, J. and Suortti, A.-M. (2000). Bioremediation of petroleum hydrocarboncontaminated soil by composting in biopiles. Environmental pollution, 107, 245-254. https:// doi.org/10.1016/S0269-7491(99)00144-X

Karigar, C. S. and Rao, S. S. (2011). Role of microbial enzymes in the bioremediation of pollutants: a review. Enzyme research, 2011. https://doi.org/10.4061/2011/805187

Kawahara, K., Tanaka, A., Yoon, J. and Yokota, A. (2010). Reclassification of a parathione-degrading Flavobacterium sp. ATCC 27551 as Sphingobium fuliginis. The Journal of general and applied microbiology, 56, 249-255. https://doi.org/10.2323/jgam.56.249

Kim, I., Kim, D.-U., Kim, N.-H. and Ka, J.-O. (2014). Isolation and characterization of fenobucarbdegrading bacteria from rice paddy soils. Biodegradation, 25, 383-394. https://doi.org/10.1007/ s10532-013-9667-9

Kumar, K., Devi, S. S., Krishnamurthi, K., Kanade, G. S. and Chakrabarti, T. (2007). Enrichment and isolation of endosulfan degrading and detoxifying bacteria. Chemosphere, 68, 317-322. https:// doi.org/10.1016/j.chemosphere.2006.12.076

Kumar, N. M., Muthukumaran, C., Sharmila, G. and Gurunathan, B. (2018). Genetically modified organisms and its impact on the enhancement of bioremediation. Bioremediation: Applications for Environmental Protection and Management. Springer. https://doi.org/10.1007/978-981-107485-1_4

Kumar, S., Dagar, V. K., Khasa, Y. P. and Kuhad, R. C. (2013a). Genetically modified microorganisms (GMOs) for bioremediation. Biotechnology for environmental management and resource recovery. Springer. https://doi.org/10.1007/978-81-322-0876-1_11

Kumar, S., Sharma, A. K., Rawat, S., Jain, D. and Ghosh, S. (2013b). Use of pesticides in agriculture and livestock animals and its impact on environment of India. Asian Journal of Environmental Science, 8, 51-57.

Kwon, G.-S., Kim, J.-E., Kim, T.-K., Sohn, H.-Y., Koh, S.-C., Shin, K.-S. and Kim, D.-G. (2002). Klebsiella pneumoniae KE-1 degrades endosulfan without formation of the toxic metabolite, endosulfan sulfate. FEMS microbiology letters, 215, 255-259. https://doi. org/10.1111/j.1574-6968.2002.tb11399.x

Kwon, G.-S., Sohn, H.-Y., Shin, K.-S., Kim, E. and Seo, B.-I. (2005). Biodegradation of the organochlorine insecticide, endosulfan, and the toxic metabolite, endosulfan sulfate, by Klebsiella oxytoca KE-8. Applied microbiology and biotechnology, 67, 845-850. https://doi. org/10.1007/s00253-004-1879-9

Liu, Y., Hou, Q., Liu, W., Meng, Y. and Wang, G. (2015). Dynamic changes of bacterial community under bioremediation with Sphingobium sp. LY-6 in buprofezin-contaminated soil. Bioprocess and biosystems engineering, 38, 1485-1493. https://doi.org/10.1007/s00449-015-1391-x

Lukić, B., Panico, A., Huguenot, D., Fabbricino, M., Van Hullebusch, E. D. and Esposito, G. (2017). A review on the efficiency of landfarming integrated with composting as a soil remediation treatment. Environmental Technology Reviews, 6, 94-116. https://doi.org/10.1080/21622515.2 017.1310310

Mahmood, I., Imadi, S. R., Shazadi, K., Gul, A. and Hakeem, K. R. (2016). Effects of pesticides on environment. Plant, soil and microbes. Springer. 253-269. https://doi.org/10.1007/978-3-31927455-3_13 
Malghani, S., Chatterjee, N., Yu, H. X. and Luo, Z. (2009). Isolation and identification of profenofos degrading bacteria. Brazilian Journal of Microbiology, 40, 893-900. https://doi.org/10.1016/ S1001-0742(08)62460-2

Marin, J., Hernandez, T. and Garcia, C. (2005). Bioremediation of oil refinery sludge by landfarming in semiarid conditions: Influence on soil microbial activity. Environmental research, 98, 185195. https://doi.org/10.1016/j.envres.2004.06.005

Marty, J. and Vouges, J. (1987). Purification and properties of a phenylcarbamate herbicide degrading enzyme of Pseudomonas alcaligenes isolated from soil. Agricultural and biological chemistry, 51, 3287-3294. https://doi.org/10.1080/00021369.1987.10868593

Massiha, A., Pahlaviani, M. R. M. K. and Issazadeh, K. (2011). Microbial degradation of pesticides in surface soil using native strain in Iran. https://doi.org/10.1007/s10532-007-9116-8.

Mcallister, K. A., Lee, H. and Trevors, J. T. (1996). Microbial degradation of pentachlorophenol. Biodegradation, 7, 1-40.https://doi.org/10.1007/BF00056556

Mena, E., Garrido, A., Hernandez, T. and Garcia, C. (2003). Bioremediation of sewage sludge by composting. Communications in soil science and plant analysis, 34, 957-971. https://doi. org/10.1081/CSS-120019102

Menzie, C. M. (1972). Fate of pesticides in the environment. Annual review of entomology, 17, 199222. https://doi.org/10.1146/annurev.en.17.010172.001215

Mohamed, M. S. (2009). Degradation of methomyl by the novel bacterial strain Stenotrophomonas maltophilia M1. Electronic Journal of Biotechnology, 12, 6-7. https://doi.org/10.4067/S071734582009000400006

Mulbry, W. W. and Karns, J. S. (1989). Purification and characterization of three parathion hydrolases from gram-negative bacterial strains. Applied and Environmental Microbiology, 55, 289-293. https://doi.org/10.1128/aem.55.2.289-293.1989

Mulbry, W. W., Karns, J. S., Kearney, P., Nelson, J., Mcdaniel, C. and Wild, J. (1986). Identification of a plasmid-borne parathion hydrolase gene from Flavobacterium sp. by southern hybridization with opd from Pseudomonas diminuta. Applied and Environmental Microbiology, 51, 926-930. https://doi.org/10.1128/aem.51.5.926-930.1986

Nag, S. K. and Raikwar, M. K. (2011). Persistent organochlorine pesticide residues in animal feed. Environmental monitoring and assessment, 174, 327-335. https://doi.org/10.1007/s10661-010$1460-1$

Namkoong, W., Hwang, E.-Y., Park, J.-S. and Choi, J.-Y.(2002). Bioremediation of diesel-contaminated soil with composting. Environmental pollution, 119, 23-31. https://doi.org/10.1016/S02697491(01)00328-1

Naphade, S. R., Durve, A. A., Bhot, M., Varghese, J. and Chandra, N. (2012). Isolation, characterization and identification of pesticide tolerating bacteria from garden soil. Eur J Exp Biol, 2, 1943-51p. https://doi.org/10.1007/s42977-021-00080-6

Odukkathil, G. and Vasudevan, N. (2013). Toxicity and bioremediation of pesticides in agricultural soil. Reviews in Environmental Science and Bio/Technology, 12, 421-444. https://doi.org/10.1007/ s00128-012-0676-x https://doi.org/10.1007/s00128-012-0676-x

Parween, T., Bhandari, P., Sharma, R., Jan, S., Siddiqui, Z. H. and Patanjali, P. (2018). Bioremediation: a sustainable tool to prevent pesticide pollution. Modern age environmental problems and their remediation. Springer. https://doi.org/10.1007/978-3-319-64501-8_12 
Pereira, J. L., Antunes, S. C., Castro, B. B., Marques, C. R., Gonçalves, A. M., Gonçalves, F. and Pereira, R. (2009). Toxicity evaluation of three pesticides on non-target aquatic and soil organisms: commercial formulation versus active ingredient. Ecotoxicology, 18, 455-463. https://doi.org/10.1007/s10646-009-0300-y

Pimentel, D. (1995). Amounts of pesticides reaching target pests: environmental impacts and ethics. Journal of Agricultural and environmental Ethics, 8, 17-29. https://doi.org/10.1007/ BF02286399

Pimmata, P., Reungsang, A. and Plangklang, P. (2013). Comparative bioremediation of carbofuran contaminated soil by natural attenuation, bioaugmentation and biostimulation. International Biodeterioration \& Biodegradation, 85, 196-204. https://doi.org/10.1016/j.ibiod.2013.07.009

Popp, J., Pető, K. and Nagy, J. (2013). Pesticide productivity and food security. A review. Agronomy for sustainable development, 33, 243-255. https://doi.org/10.1007/s13593-012-0105-x

Raimondo, E. E., Aparicio, J. D., Bigliardo, A. L., Fuentes, M. S. and Benimeli, C. S. (2020a). Enhanced bioremediation of lindane-contaminated soils through microbial bioaugmentation assisted by biostimulation with sugarcane filter cake. Ecotoxicology and environmental safety, 190, 110143. https://doi.org/10.1016/j.ecoenv.2019.110143

Raimondo, E. E., Saez, J. M., Aparicio, J. D., Fuentes, M. S. and Benimeli, C. S. (2020b). Bioremediation of lindane-contaminated soils by combining of bioaugmentation and biostimulation: Effective scaling-up from microcosms to mesocosms. Journal of Environmental Management, 276, 111309. https://doi.org/10.1016/j.jenvman.2020.111309

Saber, D. L. and Crawford, R. L. (1985). Isolation and characterization of Flavobacterium strains that degrade pentachlorophenol. Applied and Environmental Microbiology Journal, 50, 1512-1518. https://doi.org/10.1128/aem.50.6.1512-1518.1985

Sato, Y., Tsukamoto, T. and Sato, M. (1999). Rapid degradation of carbaryl by two novel strains of Arthrobacter spp. isolated from forest soil. Journal of Forest Research, 4, 275-280. https://doi. org/10.1007/BF02762783

Scott, C., Begley, C., Taylor, M. J., Pandey, G., Momiroski, V., French, N., Brearley, C., Kotsonis, S. E., Selleck, M. J. and Carino, F. A. (2011). Free-Enzyme Bioremediation of Pesticides: A case study for the enzymatic remediation of organophosphorous insecticide residues. Pesticide Mitigation Strategies for Surface Water Quality. ACS Publications. 155-174 https://doi.org/ 10.1021/bk-2011-1075.ch011

Scott, C., Pandey, G., Hartley, C. J., Jackson, C. J., Cheesman, M. J., Taylor, M. C., Pandey, R., Khurana, J. L., Teese, M. and Coppin, C. W. (2008). The enzymatic basis for pesticide bioremediation. Indian Journal of Microbiology, 48, 65. https://doi.org/10.1007/s12088-008-0007-4

Sethunathan, N. and Yoshida, T. (1973). A Flavobacterium sp. that degrades diazinon and parathion. Canadian Journal of Microbiology, 19, 873-875. https://doi.org/10.1139/m73-138

Sharma, A., Kumar, V., Shahzad, B., Tanveer, M., Sidhu, G. P. S., Handa, N., Kohli, S. K., Yadav, P., Bali, A. S. and Parihar, R. D. (2019). Worldwide pesticide usage and its impacts on ecosystem. SN Applied Sciences, 1, 1446. https://doi.org/10.1007/s42452-019-1485-1

Sharma, N. and Singhvi, R. (2017). Effects of chemical fertilizers and pesticides on human health and environment: a review. International journal of agriculture, environment and biotechnology, 10, 675-680. https://doi.org/10.5958/2230-732X.2017.00083.3 
Silva, V., Mol, H. G., Zomer, P., Tienstra, M., Ritsema, C. J. and Geissen, V. (2019). Pesticide residues in European agricultural soils-A hidden reality unfolded. Science of the Total Environment, 653, 1532-1545. https://doi.org/10.1016/j.scitotenv.2018.10.441

Singh, A. and Ward, O. P. (2004). Biodegradation and bioremediation, Springer Science \& Business Media.

Singh, B. K., Walker, A., Morgan, J. A. W. and Wright, D. J. (2004). Biodegradation of chlorpyrifos by Enterobacter strain B-14 and its use in bioremediation of contaminated soils. Applied and Environmental Microbiology Journal, 70, 4855-4863. https://doi.org/10.1128/AEM.70.8.48554863.2004

Smith, A. R. and Beadle, C. A. (2008). Induction of enzymes of 2, 4-dichlorophenoxyacetate degradation in Burkholderia cepacia 2a and toxicity of metabolic intermediates. Biodegradation, 19, 669-681. https://doi.org/10.1007/s10532-007-9172-0

Smith, T. M. and Stratton, G. W. (1986). Effects of synthetic pyrethroid insecticides on nontarget organisms. Residue reviews. Springer. https://doi.org/10.1007/978-1-4612-4934-4_4

Sreenivasulu, C. and Aparna, Y. (2001). Bioremediation of methylparathion by free and immobilized cells of Bacillus sp. isolated from soil. Bulletin of Environmental Contamination and Toxicology, 67, 98-105. https://doi.org/10.1007/s00128-001-0096-9

Stephenson, G. R., Coats, J. and Yamamoto, H. Pesticide use and world food production: risks and benefits. Expert Committee on Weeds Comité d'experts en malherbologie. Proceedings of the 2000 National Meeting, 2001. Citeseer, 9-15.

Struthers, J., Jayachandran, K. and Moorman, T. (1998). Biodegradation of atrazine by Agrobacterium radiobacter J14a and use of this strain in bioremediation of contaminated soil. Applied and Environmental Microbiology Journal, 64, 3368-3375. https://doi.org/10.1128/AEM.64.9.33683375.1998

Suciu, N. A., Ferrari, F., Vasileiadis, S., Merli, A., Capri, E. and Trevisan, M. (2013). Pesticides water decontamination in oxygen-limited conditions. Journal of Environmental Science and Health, Part B, 48, 793-799. https://doi.org/10.1080/03601234.2013.781346

Sun, Y., Kumar, M., Wang, L., Gupta, J. and Tsang, D. C. (2020). Biotechnology for soil decontamination: opportunity, challenges, and prospects for pesticide biodegradation. Bio-based materials and biotechnologies for eco-efficient construction. Elsevier. https://doi.org/10.1016/ B978-0-12-819481-2.00013-1

Tang, M. and You, M. (2012). Isolation, identification and characterization of a novel triazophosdegrading Bacillus sp.(TAP-1). Microbiological research, 167, 299-305. https://doi. org/10.1016/j.micres.2011.10.004

Tatar, S., Yildirim, N. C., Serdar, O. and Erguven, G. O. (2020). Can toxicities induced by insecticide methomyl be remediated via soil bacteria Ochrobactrum thiophenivorans and Sphingomonas melonis? Current Microbiology, 77, 1301-1307. https://doi.org/10.1007/s00284-020-02042-y

Uqab, B., Mudasir, S. and Nazir, R. (2016). Review on bioremediation of pesticides. J Bioremediat Biodegrad, 7, 2. https://doi.org/10.4172/2155-6199.1000343

Van Der Werf, H. M. (1996). Assessing the impact of pesticides on the environment. Agriculture, Ecosystems \& Environment, 60, 81-96. https://doi.org/10.1016/S0167-8809(96)01096-1

Van Gestel, K., Mergaert, J., Swings, J., Coosemans, J. and Ryckeboer, J. (2003). Bioremediation of diesel oil-contaminated soil by composting with biowaste. Environmental pollution, 125, 361368. https://doi.org/10.1016/S0269-7491(03)00109-X 
Varo, I., Serrano, R., Pitarch, E., Amat, F., Lopez, F. and Navarro, J. (2002). Bioaccumulation of chlorpyrifos through an experimental food chain: study of protein HSP70 as biomarker of sublethal stress in fish. Archives of environmental contamination and toxicology, 42, 229-235. https://doi.org/10.1007/s00244-001-0013-6

Varshney, K. (2019). Bioremediation of pesticide waste at contaminated sites. Journal of Emerging Technologies and Innovative Research, 6, 128-134.

Vasilyeva, G. and Strijakova, E. (2007). Bioremediation of soils and sediments contaminated by polychlorinated biphenyls. Microbiology, 76, 639-653. https://doi.org/10.1134/ S002626170706001X

Wang, G.-L., Wang, L., Chen, H.-H., Shen, B., Li, S.-P. and Jiang, J.-D. (2011). Lysobacter ruishenii sp. nov., a chlorothalonil-degrading bacterium isolated from a long-term chlorothalonilcontaminated soil. International journal of systematic and evolutionary microbiology, 61, 674679. https://doi.org/10.1099/ijs.0.020990-0

Wang, 1., Zhang, 1., Chen, h., Tian, q. \& Zhu, g. (2005). Isolation of a triazophos-degrading strain Klebsiella sp. E6 effectively utilizing triazophos as sole nitrogen source. FEMS microbiology letters, 253, 259-265. https://doi.org/10.1016/j.femsle.2005.09.044

Wang, S., Zhang, C. and Yan, Y. (2012). Biodegradation of methyl parathion and p-nitrophenol by a newly isolated Agrobacterium sp. strain Yw12. Biodegradation, 23, 107-116. https://doi. org/10.1007/s10532-011-9490-0

Ware, G. W. (1980). Effects of pesticides on nontarget organisms. Residue reviews. Springer. https:// doi.org/10.1007/978-1-4612-6107-0_9

Werren, J. H. (2012). Symbionts provide pesticide detoxification. Proceedings of the National Academy of Sciences, 109, 8364-8365.https://doi.org/10.1073/pnas.1206194109

WHO (2010). The WHO recommended classification of pesticides by hazard and guidelines to classification 2009, World Health Organization.

Widehem, P., Aït-Aïssa, S., Tixier, C., Sancelme, M., Veschambre, H. and Truffaut, N. (2002). Isolation, characterization and diuron transformation capacities of a bacterial strain Arthrobacter sp. N2. Chemosphere, 46, 527-534. https://doi.org/10.1016/S0045-6535(01)00192-8

Yadav, I. C. and Devi, N. L. (2017). Pesticides classification and its impact on human and environment. Environmental Science and Engineering, 6, 140-158.

Yan, Q.-X., Hong, Q., Han, P., Dong, X.-J., Shen, Y.-J. and Li, S.-P.(2007). Isolation and characterization of a carbofuran-degrading strain Novosphingobium sp. FND-3. FEMS microbiology letters, 271, 207-213. https://doi.org/10.1111/j.1574-6968.2007.00718.x

Yasouri, F. (2006). Plasmid mediated degradation of diazinon by three bacterial strains Pseudomonas sp., Flavobacterium sp. and Agrobacterium sp. Asian Journal of Chemistry, 18, 2437.

Young, J. G., Eskenazi, B., Gladstone, E. A., Bradman, A., Pedersen, L., Johnson, C., Barr, D. B., Furlong, C. E. and Holland, N. T. (2005). Association between in utero organophosphate pesticide exposure and abnormal reflexes in neonates. Neurotoxicology, 26, 199-209. https:// doi.org/10.1016/j.neuro.2004.10.004

Yu, F. B., Shan, S. D., Luo, L. P., Guan, L. B. and Qin, H. (2013). Isolation and characterization of a Sphingomonas sp. strain F-7 degrading fenvalerate and its use in bioremediation of contaminated soil. Journal of Environmental Science and Health, Part B, 48, 198-207. https://doi.org/:10.10 80/03601234.2013.730299 
Zapata, A., Oller, I., Sirtori, C., Rodríguez, A., Sánchez-Pérez, J., López, A., Mezcua, M. and Malato, S. (2010). Decontamination Of Industrial Wastewater Containing Pesticides By Combining LargeScale Homogeneous Solar Photocatalysis And Biological Treatment. Chemical Engineering Journal, 160, 447-456. https://doi.org/10.1016/j.cej.2010.03.042

Zhang, H., Yuan, X., Xiong, T., Wang, H. and Jiang, L. (2020). Bioremediation OfCo-Contaminated Soil With Heavy Metals And Pesticides: Influence Factors, Mechanisms And Evaluation Methods. Chemical Engineering Journal, 398, 125657. https://doi.org/10.1016/j.cej.2020.125657

Zhang, M.-Y., Ying, T., Ye, Z., Jun, W., Yong-Ming, L., Christie, P., Zhen-Gao, L. and Udeigwe, T. (2014). Isolation and characterization of chlorothalonil-degrading bacterial strain $\mathrm{H} 4$ and its potential for remediation of contaminated soil. Pedosphere, 24, 799-807. https://doi. org/10.1016/S1002-0160(14)60067-9

Zhang, W. (2018). Global pesticide use: Profile, trend, cost/benefit and more. Proceedings of the International Academy of Ecology and Environmental Sciences, 8, 1. 